\title{
Household Characteristics of Eco-tourism and Impact on Poverty Alleviation (Study in Lubuk Beringin Village, Bungo District)
}

\author{
Aminah \\ Doctoral Student in Economics Science \\ University of Brawijaya, Indonesia \\ Malang, Indonesia \\ ammyaminah1210@yahoo.co.id \\ Susilo \\ Lecturer at Economics Department \\ University of Brawijaya, Indonesia \\ Malang, Indonesia
}

\author{
Khusnul Ashar \\ Lecturer at Economics Department \\ University of Brawijaya, Indonesia \\ Malang, Indonesia
}

Putu Mahardika Adi Saputra

Lecturer at Economics Department

University of Brawijaya, Indonesia

Malang, Indonesia

\begin{abstract}
The purpose of this study was to determine the effect of household characteristics on ecotourism and its impact on poverty alleviation in Lubuk Beringin Village. Ecotourism development is one of the keys to economic improvement towards poverty alleviation. The methodology used in this study is descriptive quantitative with a survey method approach. The characteristics of households have a large impact on the development of ecotourism and poverty alleviation. Gender of the head of the household is an important aspect of the development of ecotourism and poverty alleviation. The average of the asset, health, and education of household members become the assets for the ecotourism development, however, the household size, dependency ratio, and employer also provides an important influence on the development. Research results show: 1. Household characteristics directly have a positive and significant effect on ecotourism; 2. Household characteristics directly have a positive and significant effect on poverty alleviation; 3 . Household characteristics directly have a positive and significant effect on poverty alleviation through ecotourism. The implications of this study can be used as a basic consideration for local government or private sector for the ecotourism development as one of the programs on poverty alleviation in Lubuk Beringin Village.
\end{abstract}

Keywords- Eco-tourism, household characteristic, poverty alleviation

\section{INTRODUCTION}

Poverty alleviation has a very big challenge to be achieved because the problems and phenomena of poverty have diverse characteristics. The development program designed by the Bungo District government focused on poverty alleviation through the development of nature-based tourism, especially ecotourism. In line to the matter, Bungo Regency has biological wealth and diversity of ecosystems, which are resources that should be grateful for, protected, and managed to realize regional development goals. The potential that is owned is the engine of growth for regional development. In accordance with the research that discusses the development of a segmented change in the tourismbased economy in Kazbegi, Georgia (Gugushvili et al. 2017). "Indicators of a household's characteristics of a region can be seen from household size, dependency ratio, average household head gender, assets, employment, health and education of the average household member can also influence poverty rates" (World Bank 2009). That “...Most existing multidimensional poverty measures, such as the global-MPI and the MPI-LA, use the household as the unit of analysis, which means that the multidimensional poverty condition of the household is equated with the multidimensional poverty condition of all its members; accordingly, these measures ignore the intra-household inequalities and are gender-insensitive..." (EspinozaDelgado \& Klasen 2018).

The Australian Department of Tourism (Black, 1999) in Fandeli and Mukhlison, (2000) which defines "ecotourism is nature-based tourism by including aspects of education and interpretation of the natural environment and culture of the community with ecological conservation". According to the World Bank, (2003) in poverty resolution is "The denial of choice and opportunities most basic for human development to lead a long healthy, creative life and enjoy a decent standard of living freedom, self esteem and the respect of other".

TABLE I. MAIN DETERMINANT OF POVERTY

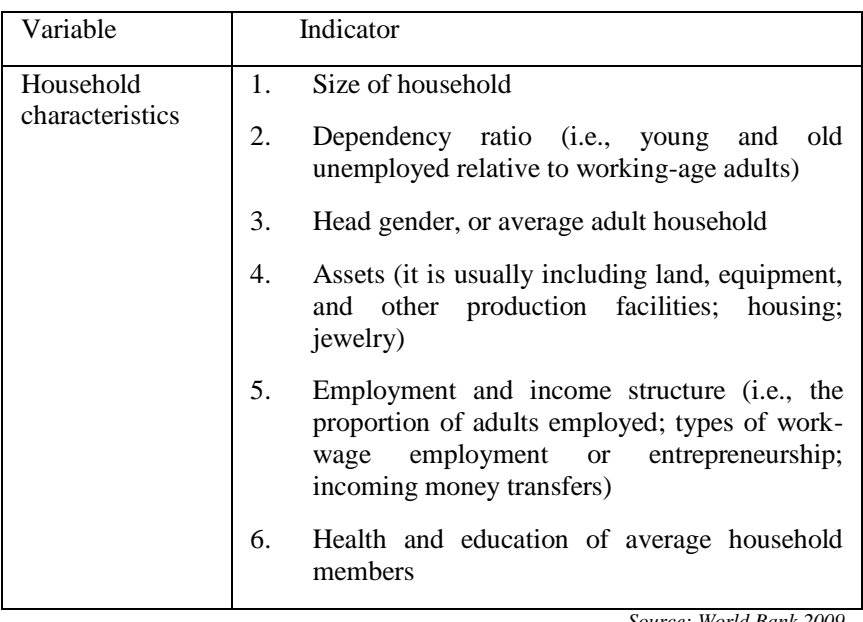


Anwar (2012: 15) "by increasing welfare, people are free from poverty and enjoy life better. Income from a person is the result of sales from the factors of production they have in the production sector" (Boediono, 1996: 170).

This problem is also faced by the Bungo Regency government, especially in Lubuk Beringin Village as the locus of this study. The Lubuk Beringin village community has a low education background, and on average, the livelihood of the villagers are farmers. Starting from the description described above, the researcher is interested in reviewing "Household Characteristics of Eco-tourism and Impact on Poverty Alleviation (study in Lubuk Beringin Village, Bungo District).”

The formulation of the problem of this research is: How does the influence of household characteristics on poverty alleviation through ecotourism in Lubuk Beringin Village? While the purpose of this study is: To determine the effect of household characteristics on poverty alleviation through ecotourism in Lubuk Beringin Village.

\section{RESEARCH METHODOLOGY}

This type of research is quantitative descriptive analysis with a survey method that uses a list of questions to respondents using Path Analysis, assisted by using software Smart PLS versi 2.0. This research is to systematically explain the data or characteristics of a particular population or a particular field. This research was conducted in Lubuk Beringin Village, Bathin III Ulu Sub-District, Bungo Regency, Jambi Province. The number of samples for the Lubuk Beringin Village Household is 106 households, (include indigenous stakeholders in Lubuk Beringin Village.

\section{A. Household Characteristics (X)}

To calculate Household Characteristics (X), there are six (6) sub-variables, namely:

1. Size household (X1)

2. Dependency Ratio (X2)

3. Gender of the Household Head (X3)

4. Assets (X4)

5. Employment (X5)

6. Average Health and Education of Household Members (X6)

\section{B. Ecotourism $(Z)$}

To calculate the Regional Characteristics (Z), there are seven (7) variables, such as:

\section{Economic benefits $(\mathrm{Z} 1)$ \\ 2. Planning and Control (Z2) \\ 3. Infrastructure (Z3)}

\section{Poverty Alleviation $(Y)$}

To calculate the value of poverty alleviation in Lubuk Beringin Village, which is seen from one (1) sub-variables, namely: Income (Y1)

\section{Path Chart Testing Model}

Based on each image of factors of the variable construct measurement model described earlier, it also described in the form of a path diagram as a whole, as follows:

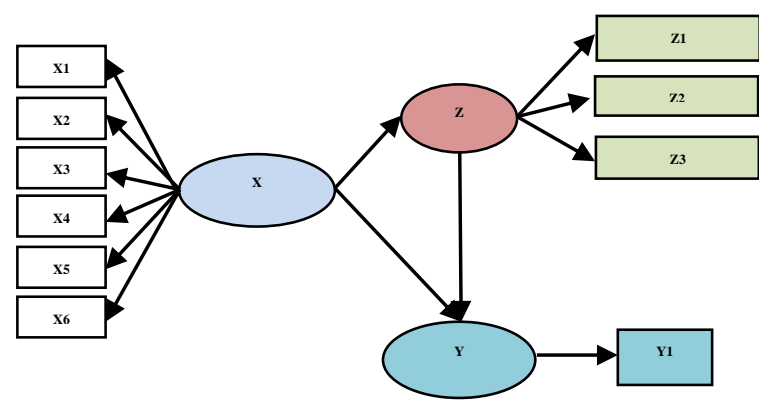

Fig. 1. Path Chart Testing Model

\section{HYPOTHESIS}

Hypotheses in this study are as follows:

H1: There is a significant effect of Household characteristics on Eco-tourism in Lubuk Beringin Village

$\mathrm{H} 2$ : There is a significant influence of Household characteristics on poverty alleviation in Lubuk Beringin Village

H3: There are significant influences, namely the characteristics of Household and eco-tourism towards poverty alleviation in Lubuk Beringin Village

\section{RESULT AND DISCUSSIONS}

This research can be constructed path diagram using Smart PLS software version 2.0; the path diagram can be described as follows:

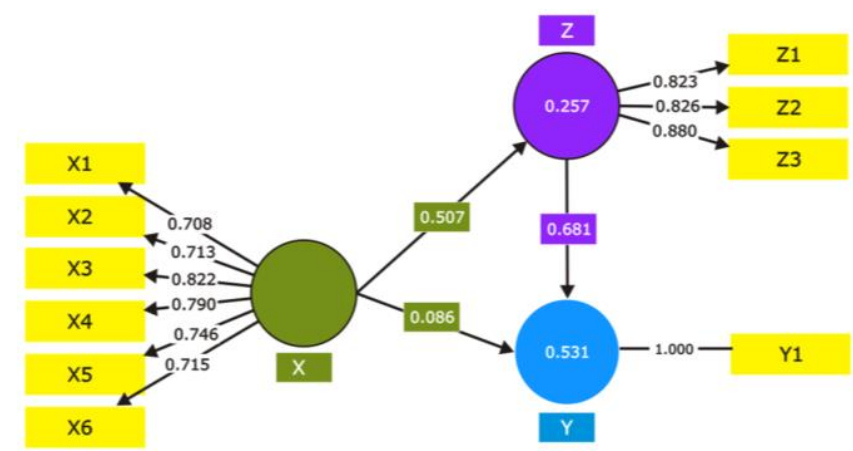

Source: Primary Data processed 2019

Fig. 2. Research Model with Partial Least Square

A. Result

TABLE II. THE GOODNESS OF FIT RESEARCH MODEL RESULTS

\begin{tabular}{|l|c|c|c|}
\hline Variable & AVE & $\begin{array}{c}\text { Composite } \\
\text { Reliability }\end{array}$ & $\begin{array}{c}\text { Cronbach's } \\
\text { Alpha }\end{array}$ \\
\hline $\begin{array}{l}\text { Household } \\
\text { Characteristics (X) }\end{array}$ & 0.563 & 0.885 & 0.848 \\
\hline Ecotourism (Z) & 0.711 & 0.880 & 0.797 \\
\hline Poverty Alleviation (Y) & 1.000 & 1.000 & 1.000 \\
\hline
\end{tabular}


TABLE III. STRUCTURAL MODEL TESTING RESULTS (INNER MODEL)

\begin{tabular}{|l|l|c|c|c|}
\hline \multicolumn{1}{|c|}{ Effect } & $\begin{array}{c}\text { Path } \\
\text { coefficient }\end{array}$ & Std. Error & T Statistics & $\begin{array}{c}\text { P- } \\
\text { value }\end{array}$ \\
\hline $\mathrm{X}>\mathrm{Z}$ & 0.507 & 0.038 & 13.333 & 0.000 \\
\hline $\mathrm{X}>\mathrm{Y}$ & 0.086 & 0.037 & 2.320 & 0.021 \\
\hline $\mathrm{X}>\mathrm{Z}->\mathrm{Y}$ & 0.345 & 0.030 & 11.453 & 0.000 \\
\hline $\mathrm{Z}->\mathrm{Y}$ & 0.681 & 0.030 & 22.436 & 0.000 \\
\hline Note: & \multicolumn{3}{|l}{} \\
\hline $\mathrm{X}=$ Household characteristics \\
\hline $\mathrm{Z}=$ Ecotourism \\
\hline Y = Poverty Alleviation
\end{tabular}

$\mathbf{X} \rightarrow \mathbf{Z} \quad$ Household characteristics have a significant positive effect on ecotourism, by increasing household characteristics will improve ecotourism.

$\mathbf{X} \rightarrow \mathbf{Y} \quad$ The characteristics of households have a significant positive effect on poverty alleviation, by increasing household characteristics will increase poverty alleviation.

$\mathbf{X} \rightarrow \mathbf{Z} \rightarrow \mathbf{Y}$ Characteristics of households have a significant positive effect on poverty alleviation through ecotourism, by increasing household characteristics will increase poverty alleviation through ecotourism.

1) Hypothesis examining

a) Hypothesis 1 is Household Characteristics (X) has a significant effect on Ecotourism (Z) with a path coefficient of 0.507 and a calculated $t$ value of 13.333 (> 1.96) significance of $0.000 \quad(<0.05)$, means Household Characteristics (X ) has a direct effect on Ecotourism (Z).

b) Hypothesis 2 is Household Characteristics (X) has a significant effect on Poverty Alleviation (Y) with path coefficient values of 0.086 and t count values of 2.320 (> 1.96) significance $0.021(<0.05)$, means Household Characteristics (X) direct influence on Poverty Alleviation (Y).

c) Hypothesis 3 is Household Characteristics (X) has a significant effect on Poverty Alleviation (Y) through Ecotourism (Z) with path coefficient value of 0.345 and $\mathrm{t}$ count value of $11.453(>1.96)$ significance of 0.000 (<0.05), means Characteristics Households (X) has an indirect effect on Poverty Alleviation (Y) through Ecotourism (Z).

\section{B. Discussions}

By empowering the community, existing employment is absorbed for Luber ecotourism management. As in the employment field, the absorption of women to work helps their husbands make added value to household needs that will have an economic impact. For example: by renting tires and mats for visitors or selling agricultural products such as corn, lanseh fruit (duku) and other fruits, it makes more value for the economy of the community. As Hastuti's research results, "the development of tourist villages requires an active role in the community, and in her research also uses indicators of household characteristics" (Hastuti, Purwantara, and Khotimah 2008). The size of the household is not a burden, it is the obligation of parents to fulfill their family's needs as well as the dependency ratio. Gender Contributions The head of the household is seen in the involvement of women in helping meet their needs. The assets owned by the people of Lubuk Beringin community are gardens or private rice fields, which inherited from generation to generation. The average employment of the Lubuk Beringin society as farmers with earning an average of $\leq 1.5$ million per month. Therefore, the Bungo District government has conducted a women's empowerment program through bamboo woven crafts. Mostly household members aware of health and education.

Management of Luber ecotourism by empowering the people of Lubuk Beringin society.It means that the role of household characteristics is very influential on poverty alleviation through ecotourism. The existence of Luber ecotourism can help household expenses. The economic benefits of a region, by the existence of ecotourism, it will open up business opportunities and income for the village, such as stalls, entrance tickets, tire rental, mat rentals, and selling agricultural products. Planning and control, development plans will be carried out in the Luber ecotourism area to accommodate more visitors. The Lubuk Beringin community is aware of Luber's ecotourism assets, which are very beneficial for various groups, and this has attracted the government. Infrastructure is the main aspectsof the sustainability of Luber ecotourism to support the safety and comfort of visitors. The Bungo District Government, together with the Lubuk Beringin community built and improved various infrastructures needed by Luber ecotourism. Socially, togetherness to promote ecotourism in Luber. Even now, there is limited infrastructure available in this area; the HP signal tower is not available yet, lodging, ATM, Puskesmas, watchtower, and bridge. Poverty, in terms of income, is still below the UMR (regional minimum wage) of Bungo Regency. Economically, Luber ecotourism has helped an active role in alleviating the poverty of the Lubuk Beringin community sustainably.

\section{CONCLUSION}

The characteristics of households have a very active role, as women are opening up stalls, renting tires, renting mats, and selling agricultural and forest products. The community is aware of the ever-increasing needs so that additional work is needed to meet the needs. It is proven from women helping in finding a living to meet their daily needs. The existence of Luber ecotourism has significantly absorbed labor, opened business opportunities, established community empowerment that can help the community's economy. 


\section{SUGGESTION}

Judging from the discussion and results of the existing research, the author would like to discuss some suggestions to the local government of Bungo County:

1. To the local government of Bungo Regency to continue to hold trainings that discuss planning, supervision, management, policy making, management, reporting and bookkeeping. Related to accepting the meeting point of conflict that discusses the community in managing ecotourism so that it can be prepared based on policies that are right on target.

2. To the local government of Bungo Regency to budget for needed infrastructure such as: road improvements from the city to ecotourism, construction of bridges, signposts, and street lighting and tourist areas.

\section{REFERENCES}

[1] Ashley, Caroline., DilysRoe and Harold Goodwin.200. ProPoor Tourism Strategies: Making Tourism World For The Poor ODI (Overseas Development Institute).

[2] Bunghez, Corina Larisa, 'The Importance of Tourism to a Destination's Economy', Journal of Eastern Europe Research in Business and Economics, $2016 \quad$ (2016), 1-9 <https://doi.org/10.5171/2016.143495>

[3] Rappaport, Julian. 1987. Term of Empowerment / Exemplars of Prevention, Towarda Theory for Household Physchology. American Journal of Household Physchology. Vol: 15.No. 2. 1987

[4] Roe, Dilys and Penny Urquhart. 2001. Pro-Poor Tourism: Harnessing the World's Largest Industri for the World's Poor, IIED (International Institute for Enviorenment and Development). London

[5] Saepudin, Pudin. 2016. Analisis Peranan Pro-Poor Tourism Dalam Meningkatkan Kesejahteraan Masyarakat Miskin Di Desa Wisata Pasanggrahan Purwakarta. Barista. Vol: 3. No. 1.

[6] Scheyvens, Regina and Janet H. Momsen. 2008. Tourism and Proverty Reduction: Issues for Small Island States. Tourism Geographies. Vol: 10. No. 1. pp. 22-41.

[7] UNWTO. 2013. Sustainable Tourism for Development. World Tourism Organization. Madrid. Spain.

[8] World Bank. 2003. East Asia Urban Working Paper Series, Kota-Kota Dalam Transmisi: Tinjauan Sektor Perkotaan Pada era Desentralisasi di Indonesia. Urban Sector Development Unit Infrastructure Departement East Asia and Pacific Region The World Bank. Jakarta.

[9] _ 2009. Handbook on Poverty and Inequality. The World Bank. Washington, DC. USA

[10] World Tourism Organization. 2004. Indicators Of Sustainable Development for Tourism Destinations. World Tourism Organization. Madrid, Spain. 